\section{Giant adrenal myelolipoma associated with 21-hydroxylase deficiency: unusual association mimicking an androgen-secreting adrenocortical carcinoma}

\author{
Mielolipoma adrenal gigante associado à deficiência \\ da 21-hidroxilase: associação não usual simulando um \\ carcinoma adrenocortical secretor de androgênios
}

Lívia Mara Mermejo', Jorge Elias Junior'2, Fabiano Pinto Saggioro ${ }^{3}$, Silvio Tucci Junior ${ }^{4}$, Margaret de Castro', Ayrton Custódio Moreira', Paula C. Lamparelli Elias'

\section{SUMMARY}

The objective of this study was to describe a case of giant myelolipoma associated with undiagnosed congenital adrenal hyperplasia (CAH) due to 21-hydroxylase $(210 \mathrm{H})$ deficiency. Five seven year-old male patient referred with abdominal ultrasound revealing a left adrenal mass. Biochemical investigation revealed hyperandrogenism and imaging exams characterized a large heterogeneous left adrenal mass with interweaving free fat tissue, compatible with the diagnosis of myelolipoma, and a $1.5 \mathrm{~cm}$ nodule in the right adrenal gland. Biochemical correlation has brought concerns about differential diagnosis with adrenocortical carcinoma, and surgical excision of the left adrenal mass was indicated. Anatomopathologic findings revealed a myelolipoma and multinodular hyperplasic adrenocortex. Further investigation resulted in the diagnosis of $\mathrm{CAH}$ due to $210 \mathrm{H}$ deficiency. Concluded that $\mathrm{CAH}$ has been shown to be associated with adrenocortical tumors. Although rare, myelolipoma associated with $\mathrm{CAH}$ should be included in the differential diagnosis of adrenal gland masses. Moreover, CAH should always be ruled out in incidentally detected adrenal masses to avoid unnecessary surgical procedures. Arq Bras Endocrinol Metab. 2010;54(4):419-24

\section{SUMÁRIO}

O objetivo deste trabalho foi descrever um caso de mielolipoma gigante associado à hiperplasia adrenal congênita (HAC) por deficiência da 21-hidroxilase (21OH). Paciente do sexo masculino, 57 anos de idade, encaminhado por achado ultrassonográfico de massa adrenal esquerda. Investigação bioquímica revelou hiperandrogenismo e exames de imagem revelaram grande lesão sólida em adrenal esquerda de aspecto heterogêneo, entremeada de tecido gorduroso, compatível com diagnóstico de mielolipoma, e um nódulo de 1,5 cm na adrenal direita. Os achados bioquímicos sugeriam o diagnóstico de carcinoma adrenocortical, indicando cirurgia para retirada da massa adrenal esquerda. $\mathrm{O}$ anatomopatológico confirmou mielolipoma e hiperplasia multinodular do córtex adrenal. A investigação subsequente diagnosticou HAC por deficiência da $210 \mathrm{H}$. Concluiu-se que a HAC tem sido descrita em associação com tumores adrenocorticais. Apesar de raro, o mielolipoma associado à HAC deve ser incluído nas possibilidades diagnósticas de massa adrenal. Adicionalmente, a HAC deve ser sempre afastada nos casos de massa adrenal de achado incidental, evitando cirurgias desnecessárias. Arq Bras Endocrinol Metab. 2010;54(4):419-24
Divisão de Endocrinologia, Departamento de Clínica Médica, Faculdade de Medicina de Ribeirão Preto, Universidade de São Paulo (FMRP-USP), Ribeirão Preto, SP, Brazil ${ }^{2}$ Divisão de Radiologia, Departamento de Clínica Médica, FMRP-USP, Ribeirão Preto, SP, Brazil ${ }^{3}$ Departamento de Patologia, FMRP-USP, Ribeirão Preto, SP, Brazil ${ }^{4}$ Departamento de Cirurgia e Anatomia, FMRP-USP, Ribeirão Preto, SP, Brazil

Correspondence to: Paula C. Lamparelli Elias Divisão de Endocrinologia, Departamento de Clínica Médica, FMRP-USP

Av. Bandeirantes, 3900 14048-900 - Ribeirão Preto, SP, Brazil

lamparelli@hotmail.com

Received on Oct/23/2009 Accepted on Jan/13/2010 


\section{INTRODUCTION}

drenal myelolipomas are relatively uncommon beAnign tumors, usually small and unilateral. They are usually found incidentally and rarely present as giant myelolipomas (1). They are composed of mature adipose cells and haematopoietic myeloid cells $(2,3)$. Although usually asymptomatic, myelolipomas can cause pain upon the occurrence of hemorrhage, necrosis or compression. Occasionally, they can occur concomitantly with other lesions such as cortical adenoma (2-4), ganglioneuroma (5), carcinoma (6), pheochromocytoma (7), or $\mathrm{CAH}$ (8). Although characteristically non-functioning, there have been a few reports of myelolipomatous masses associated with adrenocortical hypersecretion $(8,9)$. On radiologic evaluation, they typically present a high fat content that gives them a pathognomonic appearance on CT and MRI images $(10,11)$. On CT, the presence of low attenuation fat in the lesion, which has a density of $-30 \mathrm{HU}$, is a specific and diagnostic finding. On MRI, the fat components in the lesion demonstrate high signal on T1- and T2-weighted images and lose signal on Tl-fat-saturated images resembling intra-abdominal fat $(10,12)$. However, the presence of hemorrhage and necrosis features can emulate the radiological aspect of adrenocortical carcinoma (10).

In this report, we describe an uncommon case of a 57 -year-old man with a giant myelolipoma presented as an adrenal mass with a heterogeneous appearance on radiologic evaluation associated with hyperandrogenism resulting in preoperative diagnosis of adrenocortical carcinoma. The anatomopathologic findings revealed a myelolipoma, and further investigation resulted in the associated diagnosis of $\mathrm{CAH}$ due to $210 \mathrm{O}$ deficiency.

\section{CASE REPORT}

A 57-year-old Brazilian male patient was referred to the Endocrine Division in June 2008 with abdominal pain and an abdominal ultrasound revealing a left adrenal mass of $12 \times 9 \times 12 \mathrm{~cm}$. He was father of two daughters aged 32 and 34 years. At admission, the patient weighed $56.8 \mathrm{~kg}$ and was $160 \mathrm{~cm}$ tall, with a body mass index of $22 \mathrm{~kg} / \mathrm{m}^{2}$. He had a blood pressure of $100 / 70$ $\mathrm{mmHg}$ and a heart rate of 72 beats $/ \mathrm{min}$. Other physical examination was unremarkable, except by slightly decreased and hard testis $(3.5 \times 2 \mathrm{~cm}$ bilaterally). There was no clinical evidence of Cushing's syndrome, hyperaldosteronism or pheochromocytoma. A laboratory screening for adrenal incidentaloma demonstrated su- ppressed plasma cortisol levels after $1 \mathrm{mg}$ overnight dexamethasone $(33 \mathrm{nmol} / \mathrm{l}$; normal $<50)$; normokalemia (4.3 mmol/L; normal range 3.5-5); normal urinary metanephrines $(502 \mathrm{nmol} / 24 \mathrm{~h}$; normal range 31 1167 ) and urinary normetanephrines (1147 nmol/24h; normal range 240-2459), and plasma catecholamines (3.6 nmol/L; normal range 0.7-3.9); normal DHEAS ( $4 \mu \mathrm{mol} / \mathrm{L}$; normal range 6.5-9.1); normal testosterone (13 nmol/L; normal 8.7-31.2 range), and elevated androstenedione (74 nmol/L; normal range 2.1-8.7). CT and MRI exams have characterized the lesion as a large heterogeneous left adrenal soft tissue mass with substantial amount of interweaving free fat tissue. There was also a $1.5 \mathrm{~cm}$ nodule with similar features in the right adrenal gland (Figure 1).

Although the imaging features were typical for myelolipoma, the biochemical findings showing androstenedione hypersecretion associated with a large adrenal mass led to a preoperative diagnosis hypothesis of androgen secreting adrenocortical carcinoma. Patient underwent open left adrenalectomy. The intraoperatory findings demonstrated a $15 \times 10 \mathrm{~cm}$ left adrenal circumscribed mass which was completely excised, and a small pigmented right adrenal mass of around $1.5 \mathrm{~cm}$, that was not removed due to its benign appearance. Pathological findings revealed an enlarged left adrenal gland with a yellow and tan circumscribed mass of $15 \mathrm{~cm}$ in its largest diameter that weighed $585 \mathrm{~g}$. At the microscopy the tumor was characterized as a myelolipoma that rose on a multinodular hyperplasic adrenocortex (Figure 2).

The patient postoperative recovery was unremarkable, but the androgens remained elevated on the fifth day after surgery (Table 1 ). To rule out a potentially unsuccessful surgery and to diagnose a suspected CAH, measurement of basal and post $\mathrm{ACTH}_{1-24}$ stimulation test 17OHP was performed, followed by a $2 \mathrm{mg} /$ day dexamethasone suppression test during 5 days. Basal 17OHP was $261 \mathrm{nmol} / \mathrm{L}$, reaching $342 \mathrm{nmol} / \mathrm{L} 60$ minutes after $\mathrm{ACTH}_{1-24}$ (Table 1). All androgens showed a marked suppression after 5 days of the dexamethasone suppression test, thus confirming the diagnosis of CAH (Table 1).

To further confirm CAH diagnosis, a genomic analysis was performed from the DNA of the peripheral blood leukocytes and the patient was found to be a compound heterozygous carrier of the Q318X and intron2 splicing ( $\mathrm{Sp} 2)$ mutation in the CYP21A2 gene. Later on, therapy was initiated with $5 \mathrm{mg}$ of prednisone and $0.1 \mathrm{mg}$ of fludrocortisone daily, with the androste- 
nedione level falling into normal range (Table 1 ). A low testosterone level $(3.2 \mathrm{nmol} / \mathrm{L})$ and slightly high levels of $\mathrm{LH}$ and FSH (20 and $13.2 \mathrm{IU} / \mathrm{L}$, respectively), indicate an actual primary gonadal dysfunction most likely due to long-term suppression of hypothalamicpituitary-gonadal axis.

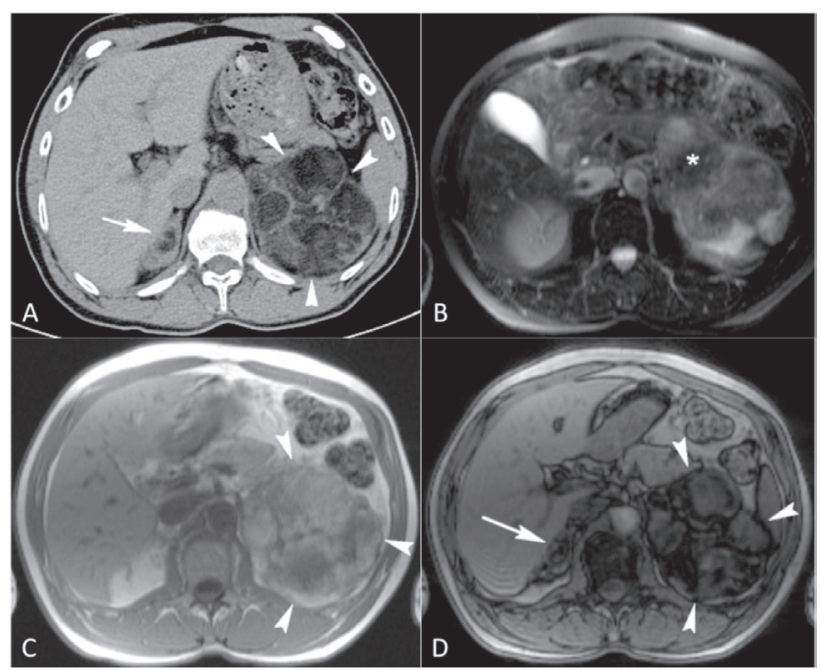

Figure 1. Axial CT image (A), axial MR T2-weighted image (B), and inphase (C) and out-of-phase (D) T1-weighted images show a large heterogeneous left adrenal soft tissue mass (arrowheads; $\mathbf{A}, \mathbf{B}$ and $\mathbf{C}$ ) with substantial amount of interweaving free fat tissue $\left({ }^{*} ; \mathbf{B}\right)$. The free fat tissue is seen as low CT density $(\mathbf{A})$ and low MR intensity (B and $\mathbf{C})$ areas within the lesion. There is also a $1.5 \mathrm{~cm}$ nodule with similar features in the right gland (white arrow; $\mathbf{A}$ and $\mathbf{D})$.

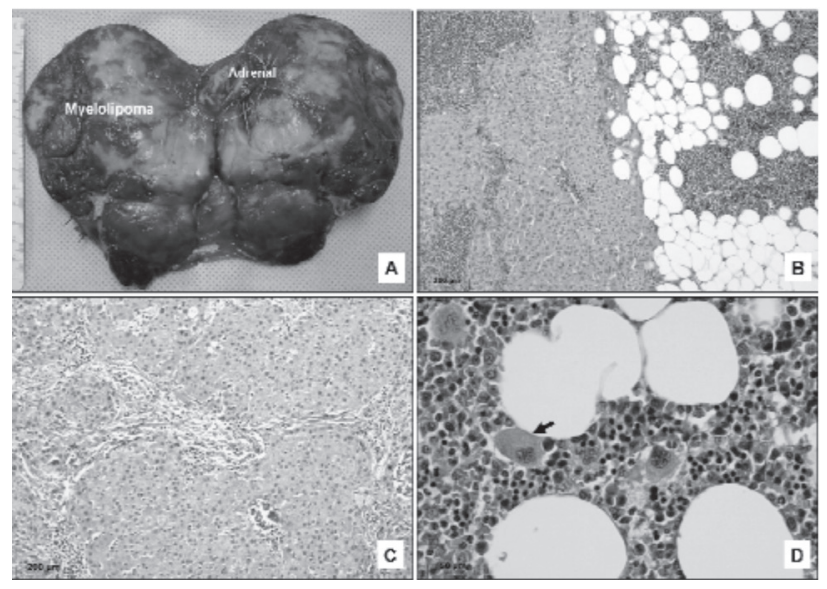

Figure 2. A. The gross pathology features of the left adrenal tumor show a yellowish to tan extradrenal mass that has grown beside the gland. B. The photomicrography shows the myelolipoma with mature adipose cells intermingled with the benign and cellular haematopoietic component (right side) that lies over a hyperplasic adrenal gland (left side). C. The photomicrography illustrates the micronodular pattern of the adrenocortical hyperplasia. D. A high-power field of the myelolipoma showing all haematopoietic lineages in maturation between the adipose cells. The arrow shows a normal megakaryocytic cell.

\section{DISCUSSION}

The pathogenesis of adrenal myelolipomas remains unclear. A variety of mechanisms are proposed to underlie the etiology of adrenal myelolipomas, such as the presence of embryonic bone marrow in adrenal tissue (3). Some evidences indicate that ACTH may have a role in the development of these tumors, demonstrated by an increase in the relative frequency of myelolipomas in patients with excessive ACTH secretion, such as in CAH $(13,14)$, Nelson's syndrome (15), and Addison's disease (3). Moreover, myeloid metaplasia in the adrenal cortex is observed in severely burned and cancer patients, two groups that are subject to long periods of intense stress (16). Indeed, myelolipomas have been associated with various forms of $\mathrm{CAH}$ like $21 \mathrm{OH}$ deficiency, 17-hydroxylase $(17 \mathrm{OH})$ deficiency and recently with $11 \beta$-hydroxylase deficiency (17). It is worth pointing out that most of these patients were either untreated or had stopped taking their medication for an extended period and were exposed for many years to chronically elevated ACTH and androgen levels which have been shown to induce transformation of adrenal cortical precursor cells into mature fat cells $(17,18)$.

To date, approximately 25 cases of myelolipomas associated with CAH have been reported. The mean age of these patients was 48 years (range 23-82 years). The characteristics of each patient and tumor are shown in table 2 . The majority of them, $19(76 \%)$, was associated with $\mathrm{CAH}$ due to $21 \mathrm{OH}$ deficiency, 4 (16\%) with $\mathrm{CAH}$ due $17 \mathrm{OH}$ deficiency and $\mathrm{l}(4 \%)$ with $\mathrm{CAH}$ due to $11 \beta$-hydroxylase deficiency. Our patient presents CAH due to $21 \mathrm{OH}$ deficiency, with a genotype Q318X / $\mathrm{Sp} 2$. Considering size and localization, the mean tumor size was $12.4 \mathrm{~cm}$ (range $1-43 \mathrm{~cm}$ ) and bilateral lesions were reported in ten cases (40\%). Jaresch and cols. (37) previously described a positive correlation between the age of $\mathrm{CAH}$ patients and the age at onset of therapy, and adrenal size; with older patients and patients who were untreated for a long period presenting the most hyperplastic adrenal glands with no correlation between tumor size and serum 17OHP concentrations. In these cases, chronic ACTH excess could induce diffuse or nodular adrenocortical hyperplasia which would later become autonomous because of oncogenic mutations in the tissue. Although under-diagnosis of $\mathrm{CAH}$ due to $2 \mathrm{lOH}$ deficiency is more frequent in male patients, as observed in our case, there was no difference in gender prevalence of myelolipomas associated with $\mathrm{CAH}$ des- 
cribed thus far in the literature, with 13 women and 12 men accounting for the casuistics. The great majority of myelolipomas associated with $\mathrm{CAH}$ are localized in the adrenal gland, however there are descriptions of myelolipomas in other locations, such as the testis (38).
There was also an increase in reports of myelolipomas in more recent years (12 reports in the last decade versus 13 from 1975 to 1997) explained by the widespread use of radiologic evaluation resulting in more diagnosis of adrenal incidentalomas (39).

Table 1. Basal hormone concentrations before, after surgery and under treatment with prednisone ( $5 \mathrm{mg}$ daily) associated with fludrocortisone (0.1 mg daily). Dexamethasone suppression test and $\mathrm{ACTH}_{1-24}$ stimulation test performed after surgery

\begin{tabular}{|c|c|c|c|c|c|c|c|}
\hline & $\begin{array}{l}\text { Before } \\
\text { surgery }\end{array}$ & $\begin{array}{l}\text { After } \\
\text { surgery }\end{array}$ & $\begin{array}{c}\text { Before } \\
\text { dexa }\end{array}$ & $\begin{array}{l}\text { After } \\
\text { dexa }\end{array}$ & $\begin{array}{c}\text { basal }^{\text {ACTH }_{1-24}} \\
\text { basal }\end{array}$ & $\begin{array}{c}\text { ACTH }_{1-24} \text { after } \\
60 \mathrm{~min}\end{array}$ & $\begin{array}{l}\text { Under } \\
\text { treatment }\end{array}$ \\
\hline DHEA-S [6.5-9.1 $\mu \mathrm{mol} / \mathrm{L}]$ & 3.9 & 1.9 & 4.6 & 0.5 & - & - & 0.2 \\
\hline Testosterone [8.7-31.2 nmol/L] & 13.4 & 10.7 & 13.5 & 0.7 & - & - & 3.2 \\
\hline Androstenedione [2.1-8.7 nmol/L] & 74 & 25.5 & 24.6 & 0.5 & _ & _- & 4.9 \\
\hline Cortisol [138-552 nmol/L] & 154 & - & - & - & 231 & 259.3 & - \\
\hline $170 \mathrm{HP}[0.9-6 \mathrm{nmol} / \mathrm{L}]$ & 218 & _ & _- & _ & 261 & 342.5 & _ \\
\hline
\end{tabular}

170HP: $17 \alpha$-hydroxyprogesterone; dexa: dexamethasone; normal range in brackets. The dexamethasone test was performed with $2 \mathrm{mg} /$ day dexamethasone during 5 days at 40 days post surgery. The $\mathrm{ACTH}_{1-24}$ test was performed with $25 \mathrm{ug}$ ACTH at 35 days post surgery.

Table 2. Reported cases of adrenal myelolipoma associated with congenital adrenal hyperplasia (CAH)

\begin{tabular}{|c|c|c|c|c|c|c|}
\hline Author & Year & САН & Age (years) & Gender & Adrenal presentation & Size (cm) \\
\hline Schindler (19) & 1975 & $210 \mathrm{H}$ & 53 & $\mathrm{~F}$ & ND & ND \\
\hline Boudreaux and cols. (20) & 1979 & $210 \mathrm{H}$ & 57 & M & Unilateral & 34 \\
\hline Barr and Giltman (21) & 1982 & $210 \mathrm{H}$ & 82 & $\mathrm{~F}$ & Unilateral & $400 \mathrm{~g}$ \\
\hline Condom and cols. (22) & 1985 & $170 \mathrm{H}$ & 50 & $\mathrm{~F}$ & Unilateral & 15 \\
\hline Sasano and cols. (23) & 1987 & $170 \mathrm{H}$ & 31 & M & Unilateral & 1 \\
\hline Sasano and cols. (23) & 1987 & $170 \mathrm{H}$ & 39 & $\mathrm{~F}$ & Bilateral & Microscopy \\
\hline Oliva and cols. (14) & 1988 & $210 \mathrm{H}$ & 34 & $\mathrm{~F}$ & Unilateral & 13 \\
\hline Miyazaki and cols. (13) & 1990 & $210 \mathrm{H}$ & 65 & $\mathrm{~F}$ & Unilateral & 5 \\
\hline Murakami and cols. (24) & 1992 & $210 \mathrm{H}$ & 41 & M & Unilateral & 3 \\
\hline Iwamoto and cols. (25) & 1993 & $210 \mathrm{H}$ & 32 & M & Bilateral & 4 and 5 \\
\hline Ravichandran and cols. (26) & 1996 & $210 \mathrm{H}$ & 51 & M & Unilateral & 11 \\
\hline Ravichandran and cols. (26) & 1996 & $210 \mathrm{H}$ & 58 & M & Bilateral & 2 and 10 \\
\hline Umpierrez and cols. (27) & 1997 & $210 \mathrm{H}$ & 47 & M & Bilateral & 5 and 2.5 \\
\hline Parenteau and cols. (28) & 2000 & $210 \mathrm{H}$ & 28 & M & Unilateral & 14 \\
\hline Nagai and cols. (29) & 2001 & $170 \mathrm{H}$ & 45 & $\mathrm{~F}$ & Unilateral & 10 \\
\hline Allison and cols. (30) & 2003 & $210 \mathrm{H}$ & 43 & $\mathrm{~F}$ & Multi and bilateral & $43 ; 8$ and 24 \\
\hline Mathew and cols. (31) & 2005 & $210 \mathrm{H}$ & 62 & $\mathrm{~F}$ & Bilateral & 12 and 6 \\
\hline Patocs and cols. (32) & 2005 & $170 \mathrm{H}$ & 37 & $\mathrm{~F}$ & Unilateral & 7 \\
\hline Kalidindi and cols. (33) & 2006 & $210 \mathrm{H}$ & 42 & M & Bilateral & 25 and 23 \\
\hline Treska and cols. (34) & 2006 & $210 \mathrm{H}$ & 56 & $\mathrm{~F}$ & Bilateral & 16 and 9 \\
\hline Sakaki and cols. (35) & 2006 & $210 \mathrm{H}$ & 69 & $\mathrm{~F}$ & Bilateral & 8 and 4 \\
\hline Nigawara and cols. (36) & 2008 & $210 \mathrm{H}$ & 66 & M & Unilateral & 3.5 \\
\hline Hagiwara and cols. (8) & 2008 & $210 \mathrm{H}$ & 43 & $\mathrm{~F}$ & Unilateral & 17 \\
\hline John and cols. (17) & 2009 & 11beta & 23 & M & Unilateral & 10 \\
\hline Present case & 2009 & $210 \mathrm{H}$ & 57 & M & Bilateral & 10 and 1.5 \\
\hline
\end{tabular}

Type of CAH: 21-hydroxylase deficiency (210H); 17-hydroxilase deficiency (170H); ND: not described. 
In conclusion, we describe a rare case of giant myelolipoma associated to $\mathrm{CAH}$ due to $21 \mathrm{OH}$ deficiency. The excessive ACTH and/or androgen secretion over a long period of time could have had a stimulatory role in the development of the adrenal myelolipoma in the present patient. However, the mechanism underlying the reduced $21 \mathrm{OH}$ reserve among incidentaloma patients and the increased occurrence of adrenal tumors in simple virilizing or late-onset $\mathrm{CAH}$ forms remains a matter of speculation. Additionally, although surgery was mandatory in the present case due to tumor symptoms and size, CAH should always be ruled out in incidentally detected adrenal masses to avoid unnecessary surgical procedures.

Acknowledgements: This work was supported by Fundação de Amparo à Pesquisa do Estado de São Paulo (Fapesp) (grant numbers 08/09276-0 and 07/58365-3).

Disclosure: no potential conflict of interest relevant to this article was reported.

\section{REFERENCES}

1. Kelekis NL, Alexopoulou E, Brountzos EN, Ladis V, Boussiotou A, Kelekis DA. Giant adrenal myelolipoma with minimal fat content in a patient with homozygous beta-thalassemia: appearance on MRI. J Magn Reson Imaging. 2003;18(5):608-11.

2. Olsson CA, Krane RJ, Klugo RC, Selikowitz SM. Adrenal myelolipoma. Surgery. 1973;73(5):665-70.

3. Plaut A. Myelolipoma in the adrenal cortex; myeloadipose structures. Am J Pathol. 1958;34(3):487-515.

4. Manassero F, Pomara G, Rappa F, Cuttano MG, Crisci A, Selli C. Adrenal myelolipoma associated with adenoma. Int $\mathrm{J}$ Urol. 2004;11(5):326-8.

5. Merchant SH, Herman CM, Amin MB, Ro JY, Troncoso P. Myelolipoma associated with adrenal ganglioneuroma. Arch Pathol Lab Med. 2002;126(6):736-7.

6. Sun X, Ayala A, Castro CY. Adrenocortical carcinoma with concomitant myelolipoma in a patient with hyperaldosteronism. Arch Pathol Lab Med. 2005;129(6):e144-7.

7. Ukimura O, Inui E, Ochiai A, Kojima M, Watanabe H. Combined adrenal myelolipoma and pheochromocytoma. J Urol. 1995;154(4):1470.

8. Hagiwara H, Usui T, KimuraT,Tagami T, Naruse M, Minamiguchi S, et al. Lack of ACTH and androgen receptor expression in a giant adrenal myelolipoma associated with 21-hydroxylase deficiency. Endocr Pathol. 2008;19(2):122-7.

9. Lamas C, Lopez LM, Lozano E, Atienzar M, Ruiz-Mondejar R, Alfaro JJ, et al. Myelolipomatous adrenal masses causing Cushing's syndrome. Exp Clin Endocrinol Diabetes. 2009;117(8):440-5.

10. Lockhart ME, Smith JK, Kenney PJ. Imaging of adrenal masses. Eur J Radiol. 2002;41(2):95-112.

11. McLoughlin RF, Bilbey JH. Tumors of the adrenal gland: findings on CT and MR imaging. AJR Am J Roentgenol. 1994;163(6):1413-8.

12. Ilias I, Sahdev A, Reznek RH, Grossman AB, Pacak K. The optimal imaging of adrenal tumours: a comparison of different methods. Endocr Relat Cancer. 2007;14(3):587-99.
13. Miyazaki Y, Yoshida M, Doi J. [A case of adrenal myelolipoma associated with adrenogenital syndrome]. Hinyokika Kiyo. 1990;36(1):35-9.

14. Oliva A, Duarte B, Hammadeh R, Ghosh L, Baker RJ. Myelolipoma and endocrine dysfunction. Surgery. 1988;103(6):711-5.

15. Maschler I, Rosenmann E, Ehrenfeld EN. Ectopic functioning adrenocortico-myelolipoma in longstanding Nelson's syndrome. Clin Endocrinol (Oxf). 1979;10(5):493-7.

16. Delarue J, Monsaingeon A. [Myeloid metaplasia in the adrenal cortex of burned subjects.]. C R Seances Soc Biol Fil. 1950;144(1112):777-8.

17. John M, Menon SK, Shah NS, Menon PS. Congenital adrenal hyperplasia 11beta-hydroxylase deficiency: two cases managed with bilateral adrenalectomy. Singapore Med J. 2009;50(2):e68-e70.

18. Selye $\mathrm{H}$, Stone $\mathrm{H}$. Hormonally induced transformation of adrenal into myeloid tissue. Am J Pathol. 1950;26(2):211-33.

19. Schindler $\mathrm{H}$. [Myelolipoma of the adrenal gland in adrenogenital syndrome]. Wien Med Wochenschr. 1975;725(48):695-7.

20. Boudreaux D, Waisman J, Skinner DG, Low R. Giant adrenal myelolipoma and testicular interstitial cell tumor in a man with congenital 21-hydroxylase deficiency. Am J Surg Pathol. 1979;3(2):109-23.

21. Barr AB, Giltman LI. Congenital adrenal hyperplasia diagnosed in an 82-year-old: case report. Va Med. 1982;109(12):844-5.

22. Condom E, Villabona CM, Gomez JM, Carrera M. Adrenal myeIolipoma in a woman with congenital 17-hydroxylase deficiency. Arch Pathol Lab Med. 1985;109(12):1116-7.

23. Sasano H, Masuda T, Ojima M, Fukuchi S, Sasano N. Congenital 17 alpha-hydroxylase deficiency: a clinicopathologic study. Hum Pathol. 1987;18(10):1002-7.

24. Murakami C, Ishibashi M, Kondo M, Ohshiro S, Fujita M, Sato S, et al. Adrenal myelolipoma associated with congenital adrenal 21-hydroxylase deficiency. Intern Med. 1992;31(6):803-6.

25. Iwamoto T, Yajima M, Tanaka H, Minagawa N, Osada T. [A case report: reversible male infertility due to congenital adrenal hyperplasia]. Nippon Hinyokika Gakkai Zasshi. 1993;84(11):2031-4.

26. Ravichandran R, Lafferty F, McGinniss MJ, Taylor HC. Congenital adrenal hyperplasia presenting as massive adrenal incidentalomas in the sixth decade of life: report of two patients with 21-hydroxylase deficiency. J Clin Endocrinol Metab. 1996;81(5):1776-9.

27. Umpierrez MB, Fackler S, Umpierrez GE, Rubin J. Adrenal myelolipoma associated with endocrine dysfunction: review of the literature. Am J Med Sci. 1997;314(5):338-41.

28. Parenteau C, Mongeau CJ, Benard B, Maheux P. Pigmented adrenal hyperplasia with myelolipomatous changes and bilateral testicular enlargement in an untreated man with 21-hydroxylase deficiency. Endocr Pract. 2000;6(3):260-3.

29. Nagai T, Imamura M, Honma M, Murakami M, Mori M. 17alphahydroxylase deficiency accompanied by adrenal myelolipoma. Intern Med. 2001;40(9):920-3.

30. Allison KH, Mann GN, NorwoodTH, Rubin BP. An unusual case of multiple giant myelolipomas: clinical and pathogenetic implications. Endocr Pathol. 2003;14(1):93-100.

31. Mathew J, Menon PS, Shah NS. An elderly lady in shock. J Postgrad Med. 2005;51(1):51-3.

32. Patocs A, Liko I, Varga I, Gergics P, Boros A, Futo L, et al. Novel mutation of the CYP17 gene in two unrelated patients with combined 17alpha-hydroxylase/17,20-lyase deficiency: demonstration of absent enzyme activity by expressing the mutant CYP17 gene and by threedimensional modeling. J Steroid Biochem Mol Biol. 2005;97(3):257-65.

33. Kalidindi RS, Hattingh L. Bilateral giant adrenal myelolipomas in a patient with known congenital adrenal hyperplasia-imaging appearan- 
ces and change in the CT morphology following steroid treatment: a case report. Abdom Imaging. 2006; DOI: 10.1007/s00261-006-9096-x.

34. Treska V, Wirthova M, Hadravska S, Mukensnabl P, KuntscherV, Kreuzberg B, et al. [Giant bilateral adrenal myelolipoma associated with congenital adrenal hyperplasia]. Zentralbl Chir. 2006;131(1):80-3.

35. Sakaki M, Izaki H, Fukumori T, Taue R, KishimotoT, Kanayama HO. Bilateral adrenal myelolipoma associated with adrenogenital syndrome. Int J Urol. 2006;13(6):801-2

36. Nigawara T, Kageyama K, Sakihara S, Takayasu S, Kawahara M, Imai A, et al. A male case of nonclassical 21-hydroxylase deficiency first manifested in his sixties with adrenocortical incidentaloma. Endocr J. 2008;55(2):291-7.
37. Jaresch S, Kornely E, Kley HK, Schlaghecke R. Adrenal incidentaloma and patients with homozygous or heterozygous congenital adrenal hyperplasia. J Clin Endocrinol Metab. 1992;74(3):685-9.

38. Adesokan A, Adegboyega PA, Cowan DF, Kocurek J, Neal DE Jr. Testicular "tumor" of the adrenogenital syndrome: a case report of an unusual association with myelolipoma and seminoma in cryptorchidism. Cancer. 1997;80(11):2120-7.

39. Seppel T, Schlaghecke R. Augmented 17 alpha-hydroxyprogesterone response to ACTH stimulation as evidence of decreased 21-hydroxylase activity in patients with incidentally discovered adrenal tumours ('incidentalomas'). Clin Endocrinol (Oxf). 1994;41(4):445-51 